\title{
ТЕХНОЛОГИЯ БИОПРИНТИНГА
} КАК ЛЕГАЛЬНЫЙ ВЫЗОВ: ОПРЕДЕЛЕНИЕ МОДЕЛИ ПРАВОВОГО РЕГУЛИРОВАНИЯ

\begin{abstract}
Аннотация. Технология 3D-печати порождает серьезные вызовы правовой системе, которая в своем развитии отстает от научно-технического прогресса. Развитие технологии 3D-печати ведет к «диджитализации» объектов материального мира, происходит стирание грании между физическим миром и цифровым пространством. Если 3D-принтинг диджитализирует объекты материального мира, то биопринтинг диджитализирует тело человека. Человек начинает зависеть от ииррового воплощения своего тела или его отдельных органов в соответствующих электронных 3D-моделях.

Биопринтинг направлен на формирование новой медицинской парадигмы, которая позволит преодолеть дефицит органов и тканей человека в сфере трансплантологии. Omкрытие возможности перепрограммирования дифрференцированных клеток и получение индуцированных плюропотентных стволовых клеток устраняет этическую и правовую проблему, связанную с использованием стволовых клеток эмбриона. Это должно быть учтено при выработке модели правового регулирования отношений, связанных с созданием биопринтных органов человека.

Биопринтные органы являются синтетическими органами, поэтому отношения, связанные с их созданием и имплантацией, нуждаются в самостоятельном правовом регулировании. Современное законодательство о трансплантологии с предусмотренными в нем запретами не учитывает особенности создания органов посредством трехмерного биопринтинга. Представляется допустимой коммерциализация отномений в сфере биопринтинга, возможность совершения возмездных сделок в данной сфере, а также ограниченный оборот "биопринтных» органов - путем распространения на них режима объектов гражданского права.

Законодательство о биомедицинских клеточных продуктах также не способно урегулировать отношения, связанные с созданием и имплантацией биопринтных человеческих органов. Возникает необходимость в принятии специального законодательного акта, направленного на регулирование отношений, возникающих на всех стадиях использования технологии биопринтинга.
\end{abstract}

Ключевые слова: технология 3D-печати, биопринтинг, биопринтный орган, тканевая инженерия, биомедицинский клеточный продукт, индуцированная плюрипотентная стволовая клетка, эмбрион, трансплантология, донорство, оборот органов и тканей человека, правовое регулирование.

DOI: 10.17803/1729-5920.2019.151.6.080-091

1 Исследованиевыполненопри финансовойподдержке РФФИврамкахнаучногопроекта №18-29-14027 мк «Концепция правового регулирования отношений по проведению геномных исследований в сфере создания и использования биопринтных человеческих органов».

(C) Богданов Д. Е., 2019

* Богданов Дмитрий Евгеньевич, доктор юридических наук, профессор кафедры гражданского права Московского государственного юридического университета имени О.Е. Кутафина (МГЮА) debogdanov@msal.ru 125993, Россия, г. Москва, ул. Садовая-Кудринская, д. 9 
Каждая человеческая жизнь бесценна. Благая цель спасения человеческой жизни является главным движителем медицинской науки вообще и трансплантологии в частности. Трансплантология за последнее время достигла поразительных успехов, поскольку стала возможной успешная трансплантация не только таких органов человека, как почки, печень, легкие и др., но даже сердца. Так, в России в течение 2017 г. было осуществлено 252 операции по трансплантации сердца².

Однако общей, глобальной проблемой является постоянный рост числа пациентов, нуждающихся в пересадке органов и острая нехватка донорских органов, необходимых для трансплантации. Так, по данным Global Observation on Donation and Transplantation, в 2016 г. в мире было осуществлено 135860 операций по пересадке органов человека, в том числе 89823 пересадки почки (40,2 \% от живых доноров), 30352 пересадки печени (19,8 \% от живых доноров), 7626 пересадок сердца, 5497 пересадок легких и 2342 пересадки поджелудочной железы. Общий рост количества трансплантаций в мире составил 7,2 \% по сравнению с 2015 г. Однако по отдельным позициям рост составил более 8 \%, например трансплантации печени (9,3 \%), легких $(8,9 \%)$, сердца $(8,5 \%)^{3}$.

По мнению А. Цукермана и Г. Лауфера, несмотря на снижение смертности в «листе ожидания», необходимо максимально использовать весь возможный донорский потенциал. Названные авторы указывают, что в США передозировка наркотиками является обычной причиной смерти так называемых «посмертных доноров». При этом многие из таких доноров являлись носителями вируса гепатита С. В европейских странах использование органов «маргинальных» доноров также становится обычной практикой ${ }^{4}$.

Заслуживает внимания и то обстоятельство, что в некоторых странах «посмертное донорство» уже приобрело не только социальный, но и расовый контекст, например в Калифорнии примерно 80 \% таких доноров являются афроамериканцами или латиноамериканцами ${ }^{5}$.

Майкл Годвин в этой связи отмечает, что несмотря на большое количество совершаемых в США операций по трансплантации органов, в лист ожидания очереди на операцию включены более 100 тыс. человек. Ежегодно около 7 тыс. таких очередников умирает, не дождавшись наступления очереди, а еще несколько тысяч человек исключаются из листа ожидания в связи с нецелесообразностью их дальнейшего лечения 6 .

Если экстраполировать указанные цифры в глобальном масштабе, то число лиц, нуждающихся в операции, и тех, кто умрет, находясь в ожидании операции, увеличится на порядки.

Все это предопределяет существование «черного рынка» человеческих органов, существование преступных сообществ, в том числе и трансграничных, вовлеченных в незаконный оборот органов и тканей человека. Спрос рождает предложение, поэтому, несмотря на практически повсеместный запрет на оборот человеческих органов, емкость данного черного рынка в глобальном масштабе составляет миллиарды долларов США.

Так, в качестве примера можно указать на дело Мастромарино (Mastromarino), рассмотренное в Нью-Йорке в 2008 г. Мастромарино был осужден на 50 лет за осквернение более чем 1800 трупов, подлежащих погребению. Это стало возможным в связи с тем, что он со своими подельниками контролировал нескольких похоронных бюро. По сути, преступной группой был организован «супермаркет» по продаже тканей и органов. Мастромарино также учредил компанию Biomedical Tissue Services (BTS), которая получила лицензию. В ходе деятельности данной преступной группы более 10000 тыс. реципиентов получили ткани и органы. Забор органов и тканей осуществлялся без их проверки на ВИЧ, гепатиты, онкологию и т.д. В резуль-

2 Готье С. В., Попцов В. Н., Колоскова Н. Н., Захаревич В. М., Шевченко А. О., Муминов И. И., Никитина Е. А., Кван В. С., Халилулин Т. А., Закирьянов А. Р., Гольц А. М. Лист ожидания трансплантации сердца ФГБУ «НМИЦ ТИО имени академика В. И. Шумакова». Тенденции за период с 2010-го по 2017 год // Вестник трансплантологии и искусственных органов. 2018. Т. XX. № 4. С. 8-13.

3 URL: http://www.transplant-observatory.org/.

4 Zuckermann A., Laufer G. Rationale Limits of Organ Donor Maximization for Heart Transplantation // Вестник трансплантологии и искусственных органов. 2018. Т. ХХ. № 4. С. 142-145.

5 Goodwin M. Body Market: Race Politics \& Private Ordering // Arizona Law Review. 2007. Vol. 49. Pp. 599-636.

6 Goodwin M. Empires of the Flesh ... 
тате ряд реципиентов были заражены соответствующими заболеваниями ${ }^{7}$. Еще больший резонанс получила книга Карлы дель Понте об участии косовских албанцев в убийствах сербов в целях последующей продажи человеческих органов и тканей. К данной преступной деятельности были причастны руководители косовских албанцев, в частности Хашим Тачи, занимавший тогда пост премьер-министра Косово ${ }^{8}$.

Следует отметить, что запрет на оборот органов и тканей человека является одним из основных принципов биоэтики. Основными аргументами против коммерциализации отношений, связанных с трансплантацией тканей и органов человека, считается то, что создание финансовых стимулов для донорства будет подрывать другой принцип биоэтики - свободного и информированного согласия донора. Финансовые стимулы будут принуждать бедных отдавать свои органы богатым. Коммерциализация трансплантологии приведет к эксплуатации бедных. Как в этой связи отмечается в литературе, «продажа органов будет равносильна рабству, поскольку слабые, уязвимые социальные группы превратятся в «ящики с инструментами», в ящики с пригодными для использования запасными частями, лишенными человечности и индивидуальности ${ }^{9}$.

Поэтому в ст. 1 Закона РФ от 22.12.1992 № 4180-1 «О трансплантации органов и (или) тканей человека» предусмотрено, что органы и ткани человека не могут быть предметом купли-продажи. Купля-продажа органов и тканей человека влечет уголовную ответственность в соответствии с законодательством Российской Федерации. Аналогичный запрет на оборот органов установлен и в законодательстве США (National Organ Transplant Act, 1984). Негативное отношение к обороту органов человека было выражено в Стамбульской декларации о трансплантационном туризме и торговле органами $(2008 \text { г. })^{10}$.

Представляет интерес, что запрет установлен именно на «оборот» в узком смысле, то есть собственно на куплю-продажу органов и тканей человека. Законодательство многих стран прямо допускают возможность «компенсации разумных расходов», связанных со сферой трансплантологии. Так, в Руководящих принципах ВОЗ по трансплантации человеческих клеток, тканей и органов предусмотрено, что запрет на продажу или покупку клеток, тканей или органов не исключает возмещения разумных и поддающихся контролю расходов, понесенных донором, включая потерю дохода, или оплату издержек, связанных с уходом, обработкой, сохранением и передачей человеческих клеток, тканей или органов для трансплантации (Руководящий принцип 5).

Поэтому все равно в сфере трансплантологии присутствуют бизнес-интересы. Специалисты отмечают, что биобанки (Tissue Banks) участвуют в глобальном «рыночном обмене», связанном с оборотом органов и тканей человека. Представители биобанков признают, что каждый труп приносит данным организациям не менее 250 тыс. долл. США чистой прибыли. Только емкость рынка человеческих почек в глобальном аспекте оценивается в 25 млрд долл. США ${ }^{11}$.

В литературе уже высказываются позиции, что следует признать очевидный факт, что объективно существует легальный рынок тканей и органов человека. В данной сфере выгоду или благо получают все, за исключением донора. М. Годвин приходит к выводу, что надо перестать закрывать глаза на очевидное и в целях сокращения черного рынка необходимо допустить коммерциализацию оборота органов. Признать их гражданско-правовую объектность и возможность донора за вознаграждение посмертно распорядиться своим органом, например с целью материального обеспечения членов своей семьи ${ }^{12}$.

Действительно, в словах М. Годвина можно услышать горькую правду, связанную с фактической коммерциализацией трансплантологии. И несмотря на все декларируемые принципы биоэтики, богатые все равно эксплуатируют бед-

7 CM.: Goodwin M. Empires of the Flesh ...

$8 \quad$ URL: https://ru.wikipedia.org/wiki/\%D0\%A2\%D0\%BE\%D1\%80\%D0\%B3\%D0\%BE\%D0\%B2\%D0\%BB\%D1\%8F_ \%D1\%87\%D0\%B5\%D0\%BB\%D0\%BE\%D0\%B2\%D0\%B5\%D1\%87\%D0\%B5\%D1\%81\%D0\%BA\%D0\%B8\%D0\%BC\% D0\%B8_\%D0\%BE\%D1\%80\%D0\%B3\%D0\%B0\%D0\%BD\%D0\%B0\%D0\%BC\%D0\%B8_\%D0\%B2_\%D0\%9A\%D0\%B E\%D1\%81\%D0\%BE\%D0\%B2\%D0\%B5.

9 CM.: Goodwin M. Body Market ...

10 URL: http://transpl.ru/files/npa/stambul_skaya_deklaraciya.pdf.

1 Goodwin M. Empires of the Flesh ...

12 Goodwin M. Body Market ... 
ных. Так, миллиардер Рокфеллер за свою жизнь перенес семь операций по пересадке сердца и две операции по пересадке почки ${ }^{13}$. Получается, что 9 человек стали «ящиками с запчастями», а 9 других умерли, ожидая операцию по пересадке органов. Данный пример заставляет вспомнить фантастическое произведение Герберта Уэллса «Машина времени», в котором будущее будет связано с разделением людей на морлоков и элоев, где одни пожирают других.

Развитие технологии тканевой инженерии (tissue engineering) является попыткой выработать новую медицинскую парадигму и преодолеть хронический дефицит органов и тканей человека.

Как указывает В. И. Севастьянов, суть технологии заключается в ее трех компонентах: во первых, это клетки, способные формировать функционирующий внеклеточный матрикс; во-вторых, подходящий биодеградируемый носитель (матрикс) для трансплантации клеток (например, органические полимеры, коллагеновые гидрогели); и в-третьих, биоактивные молекулы (цитокины, факторы роста), которые оказывают биостимулирующее действие на клетки поврежденной ткани. Клетки, как правило, - это мультипотентные мезенхимальные стволовые клетки (ММСК) и дифференцированные (специализированные, тканеспецифические) клетки. Аутологичные (собственные) или аллогенные (донорские) дифференцированные клетки получают с помощью биопсии, культивируют in vitro и впоследствии трансплантируют. Современные технологии уже создают возможность использовать организм человека в качестве биореактора для «созревания» ткани ${ }^{14}$.

Однако как отечественные, так и иностранные авторы признают, что одних «инъекционных» технологий недостаточно - необходимы каркасные технологии, которые позволяют трансплантировать именно выращенный заменитель органа. Уже имеются примеры «кар- касной» трансплантации: так, пациентке был пересажен биоинженерный эквивалент трахеи. В качестве матрикса, каркаса использовалась децеллюризованная донорская трахея (от трупа), клетки которой были "девитализированы». Потом на нее была нанесена суспензия из аутологических клеток, и впоследствии трахея с клетками реципиента была успешно трансплантирована ${ }^{15}$.

Однако данная «консервативная» методика, связанная с использованием аллогенных донорских каркасов или даже ксеногенных (например, от свиней), не способна решить всех проблем. Так, Энтони Атала указывает, что, несмотря на очевидные успехи, тканевая инженерия и регенеративная медицина имеют свои пределы, поскольку методы регенеративной медицины способны восстановить поврежденный участок ткани или органа, но не способны решить проблему замены органа ${ }^{16}$.

Необходима трехмерная печать органов, готовых к последующей трансплантации. Трехмерная печать органов в случае использования аутологических клеток устраняет риск отторжения органа. Организм получает полноценный новый орган, «напечатанный» на основе клеток самого реципиента. Таким образом, в случае использования (забора) аутологических клеток у пациента в целях последующей трехмерной печати и трансплантации органа будет отсутствовать донорство как таковое. Донорство клеточного материала будет иметь место только в случае забора аллогенных клеток другого человека (донора).

Как с юмором отмечает в этой связи Джаспер Тран, наука делает возможным биопринтинг посредством соединения, заключения "брачного союза», между концепциями 3D-печати и синтетической биологии. В качестве «матери» биопринтинга выступает технология трехмерной (3D) печати, а «отцом» синтетическая биология. В результате союза указанных технологических и научных концепций рождается технология биопринтинга ${ }^{17}$.

13 URL: https://transplantology.net/news/david-rockefeller-seventh-heart-translant/.

14 Подробный анализ технологии тканевой инженерии см.: Севастьянов В. И. Технология тканевой инженерии и регенеративной медицины // Вестник трансплантологии и искусственных органов. 2014. T. XVI. № 3. С. $93-108$.

15 См.: Von Tigerstrom B. Human Tissue Legislation and New Medical Paradigm: Governing Tissue Engineering in Canada // McGill Journal of Law and Health. 2015. Vol. 8. № 2. Pp. 1-56; Varkey M. \& Atala A. Organ Bioprinting: A Closer Look at Ethics and Politics // Wake Forest Journal of Law \& Policy. 2015. Vol. 5. Iss. 2. Рp. 275-296; Севастьянов В. И. Указ. соч.

16 Varkey M. \& Atala A. Op. cit.

17 Tran J. L. Bioprint or Not to Bioprint // North Carolina Journal of Law and Technology. 2015. Vol. 17. Iss. 1. Pp. 123-178. 
3D-печать в научной литературе обозначается в качестве примера аддитивной технологии ${ }^{18}$. В ее основе лежит соединительный метод, суть которого заключается в том, что 3D-принтер посредством последовательного соединения, наслоения "ингредиентов» (порошков, металла, полимеров и т.п.) осуществляет послойную печать нового трехмерного объекта. Работа 3D-принтера управляется ЭВМ с соответствующим программным обеспечением, при этом самой печати предшествует создание цифровой модели (прототипа) будущего трехмерного объекта (Computer aided design files - CAD-files), который может быть получен, например, посредством трехмерного сканирования.

Развитие технологии 3D-печати ведет к “диджитализации» объектов материального мира, происходит стирание границ между физическим миром и цифровым пространством, поскольку грань между цифровым прототипом и его материальным воплощением истончается до одного клика ${ }^{19}$. Как отмечает Лукас Осборн, 3D-печать становится причиной наложения друг на друга миров атомов и битов. По мере распространения и совершенствования технологии 3D-печати трехмерные цифровые шаблоны для многих продуктов станут эквивалентны их физическим аналогам. Регулирование таких файлов станет главным вызовом для правовой системы, стремящейся адаптироваться к миру 3D-печати ${ }^{20}$.

Если трехмерная печать (3D-принтинг) диджитализирует объекты материального мира, которые относятся не только к продуктам высоких технологий (например, детали и части космических или летательных аппаратов), но и товары повседневного потребления (например, посуда или обувь), то биопринтинг начинает диджитализировать самого человека, его тело. Впоследствии это может привести к своеобразной диджитализации самого бытия человека21, поскольку оно будет напрямую зависеть от его цифрового воплощения в соответствующих CAD-файлах, то есть электронных шаблонах как всего тела человека, так и его отдельных частей, отдельных тканей и органов.

B настоящее время технология 3D-печати уже активно вовлечена в сферу, связанную с «диджтализацией» человека в целях здравоохранения. Так, рядом корпораций (например, Organovo, Aspect Biosystems, TeVido Biodevices) успешно разрабатывается технология биопринтинга тканей печени и других органов человека в целях токсилогического тестирования новых лекарственных препаратов, что способствует снижению рисков причинения вреда, а также сокращает сроки испытаний новых лекарственных препаратов и связанные с этим расходы. 3D-принтинг активно используется в целях восстановления пациентов после тяжелых травм, поскольку данная технология позволяет напечатать индивидуальные протезы и импланты, учитывающие индивидуальные физиологические особенности каждого пациента. Tpexмерная печать позволяет также восстановить внешность пациента, поэтому она уже активно используется в сфере лицевой хирургии. Во многих ведущих медицинских центрах 3D-принтинг используется перед проведением сложных операций, техника которой первоначально отрабатывается на 3D-модели соответствующего органа, например перед его трансплантацией 22

Поскольку 3D-печать возможна на основе как органических, так и неорганических материалов, возникает вопрос о необходимости учета данного обстоятельства при определении модели правового регулирования соответствующих отношений. В литературе уже высказывалась позиция, что 3D-печать имплицитно предполагает, что возможно установление идентичных правил при определении модели правового регулирования отношений, связанных с 3D-печатью на основе как органических (биологических), так и неорганических мате-

18 Kennedy E. J., Giampetro-Meyer A. Gearing Up for the Next Industrial Revolution: 3D Printing, Home-based Factories and Modes of Social Control // Loyola University Chicago Law Journal. 2015. Vol. 46. Pp. 955-988.

19 Как отмечает Даниел Брэн? «Now 3D printing has thinned the border between the digital and physical such that difference can be little more than the click of a button» (см.: Brean D. H. Patent Enforcement in Cyberterritories (April 12, 2018) // Cardozo Law Review. 2019. Vol. 40. (Forthcoming). Available at SSRN: https://ssrn.com/abstract=3161823).

20 Osborn L Regulating Three-Dimensional Printing: The Converging Worlds of Bits and Atoms // San Diego Law Review. 2014. Vol. 51. P. 553, 620.

21 Tran J. L. Op. cit.

22 См. об этом: Varkey M. \& Atala A. Op. cit. 
риалов 23 . Однако, по мнению Джаспера Трана, данное предположение является ошибочным, поскольку печать из биологического материала порождает особые политико-правовые и этические вызовы ${ }^{24}$.

Основным этическим вызовом в сфере тканевой инженерии и биопринтинга является определение источника человеческих клеток, которые будут использованы при создании (печати) новых человеческих тканей и органов. В специальной литературе указывается, что человеческие клетки, используемые при технологии биопринтинга, независимо от вида устройства (например, струйные, экструзионные или лазерные биопринтеры), находятся в «стрессовой» ситуации, поэтому необходимо обеспечить их жизнеспособность в процессе как биопечати органа или ткани, так и их дальнейшего созревания в биореакторе и последующей трансплантации реципиенту. При этом человеческие органы являются сложными по своему клеточному составу. Поэтому для создания органа необходимы человеческие клетки разных видов, что предопределяет необходимость использования в биопринтинге стволовых клеток ${ }^{25}$.

Использование в биопринтинге стволовых клеток обусловлено тем, что именно данные человеческие клетки обладают такими признаками, как возможность их самовоспроизводства и потентность, то есть способность к дифференциации. Наибольшей потентностью обладают эмбриональные плюрипотентные человеческие клетки, поскольку они являются источником образования дифференцированных клеток любых тканей и органов человека.

Это порождает фундаментальный этический вызов, связанный с использованием технологии биопринтинга, а именно включение в состав «био-чернил» (bio-ink) эмбриональных стволовых клеток человека, что предопределяет необходимость уничтожения человеческих эмбрионов в целях извлечения указанных клеток.

В этой связи необходимо отметить, что в российской и зарубежной научной литературе существует дискуссия относительно правовой природы человеческого эмбриона. Так, была высказана заслуживающая внимания позиция о том, что эмбрион in vitro является источником и начальной стадией человеческого бытия, поэтому его уничтожение является правонарушением, даже если оно было совершено с целью спасения другой человеческой жизни ${ }^{26}$.

Этим обусловлен повсеместный запрет на патентование технологий, связанных с использованием человеческих эмбрионов, так называемая «моральная клауза». Так, согласно п. 4 ст. 1349 ГК РФ не могут быть объектами патентных прав: способы клонирования человека и его клон; способы модификации генетической целостности клеток зародышевой линии человека; использование человеческих эмбрионов в промышленных и коммерческих целях, а также другие результаты интеллектуальной деятельности, если они противоречат общественным интересам, принципам гуманности и морали.

Однако последние достижения в науке, в частности открытие возможности перепрограммирования дифференцированных клеток и получения индуцированных плюропотентных стволовых клеток (induced pluripotent stem cells), устраняют этическую проблему, связанную с использованием стволовых клеток эмбриона. Отпадает необходимость разрушать человеческий эмбрион либо выращивать в целях последующего биопринтинга анацефальных эмбрионов (в которых не формируется головной мозг) в матке суррогатной матери из стволовых клеток пациента27.

Многие ученые, например Энтони Атала, указывают и на тот потенциал, который возникает в случае использования для биопринтинга мезенхимальных (стромальных) соматических стволовых клеток ${ }^{28}$. Указанные клетки являются мультипотентными, поэтому они могут быть использованы в качестве первичного клеточного материала для биопринтинга различных человеческих органов ${ }^{29}$. Источником таких клеток

23 CM.: Desai D. R. \& Magliocca G. N. Patents Meet Napster: 3D Printing and the Digitization of Things // Georgetown Law Journal. 2014. Vol. 2. Pp. 1691-1715.

24 Tran J. L. Op. cit.

25 См. об этом: Varkey M. \& Atala A. Op. cit.

26 См., например: Steinbock B. The Morality of Killing Human Embryos // Journal of Law, Medicine \& Ethics. 2006. Vol. 34. Pp. 26-34.

27 URL: https://scfh.ru/papers/vsled-za-sozdatelem-tekhnologii-bioprintinga/.

28 Varkey M. \& Atala A. Op. cit.

29 См.: Zaher W. An Update of Human Mesenchymal Stem Cell Biology and Their Clinical Use // Archives Toxicology. 2014. Vol. 88. Pp. 1069-1076. 
может являться, например, костный мозг самого реципиента органа либо донорский костный мозг.

Таким образом, последние научные достижения позволяют утверждать, что технология трехмерной печати органов человека (биопринтинг) становится по крайней мере этически нейтральной, поскольку она уже не посягает на основополагающие общественные интересы, а также на принципы гуманности и морали. Это с неизбежностью должно повлиять на выработку модели правового регулирования отношений, связанных с созданием биопринтных органов человека.

Учитывая то обстоятельство, что по прогнозам компаний в сфере медицинского технологического консалтинга, например Root Analysis, биопринтинг человеческой почки станет возможным уже в 2023 г., общественные отношения, связанные с трехмерной печатью органов человека, уже в скором времени станут предметом правового регулирования.

В этой связи интересны как оптимистические, так и более реалистические позиции в иностранной научной литературе относительно готовности правовой системы к регулированию отношений в сфере биопринтинга. Так, по мнению Элизабет Келли, современный правопорядок уже в текущем состоянии способен полностью урегулировать все вопросы, которые возникают в сфере биопринтинга органов человека ${ }^{30}$. Однако другие авторы считают, что в сфере трехмерной печати в настоящее время имеет место "регулятивный беспорядок», поскольку отсутствует последовательное и непротиворечивое правовое регулирование данных отношений ${ }^{31}$. Так, Энтони Атала применительно к ситуации в США указывает, что у FDA (Food and Drug Administration) еще отсутствует нормативно установленная категория для биопринтинга, поскольку он предполагает комбинацию «продуктов», в частности лекарственных препаратов, медицинских изделий, биологических препаратов и материалов, использование которых связано с проведением хирургических процедур ${ }^{32}$.
При этом в иностранной цивилистической литературе справедливо отмечается, что биопринтные органы необходимо рассматривать и регулировать дифференцированно при их соотношении с собственно человеческими органами, поскольку первые, по сути, являются искусственными ${ }^{33}$.

Действительно, технология биопринтинга не связана с использованием донорских органов человека. Источником, материалом для биопринтинга могут быть аутологические или аллогенные клетки человека. Забор таких клеток не связан с причинением вреда здоровью донора или реципиента либо такой вред незначителен, поскольку забор биологического материала, в частности для получения меземхимальных мультипотентных клеток, возможен, например, путем биопсии костного мозга. В качестве способа получения клеток для биопринтинга может также выступать липоксация жировой ткани. Освоение технологии перепрограммирования дифференцированных клеток в плюрипотентные стволовые клетки позволит рассматривать в качестве способа получения клеток для биопринтинга даже простые мазки и соскобы.

Поэтому законодательство о трансплантологии с его запретами становится уже неадекватным для регулировании отношений, связанных с биопринтингом. Поскольку законодательство о трансплантологии, в частности Закон РФ от 22.12.1992 № 4180-1 «О трансплантации органов и (или) тканей человека», было принято в иной социальной ситуации и для решения этических вызовов, которые возникали в рамках классической трансплантологии и донорства органов человека.

Так, Джаспер Тран задается вопросом о применимости законодательства США, регулирующего отношения в сфере трансплантологии и донорства человеческих органов (National Organ Transplant Act, 1984), к отношениям, связанным с биопринтингом и трансплантацией «напечатанных» органов ${ }^{34}$.

В этой связи представляет интерес исследование проблем правового регулирования отно-

30 Kelly E. FDA Regulation of 3D-Printed Organs and Associated Ethical Challenges // University of Pennsylvania Law Review. 2018. Vol. 166. Iss. 1. Pp. 515-545.

31 Bauer H.-K. et al. Social and Legal Frame Conditions for 3D and Bioprinting in Medicine // International Journal of Computerized Dentistry. 2016. Vol. 19. Iss. 4. Pp. 293-299.

32 Varkey M. \& Atala A. Op. cit.

33 См., например: Kelly E. Op. cit.

34 Tran J. L. Op. cit. 
шений в сфере тканевого инжиниринга в Канаде, проведенное Барбарой фон Тайгерстром, которая указывает на то, что в большинстве статутов провинций Канады трансплантация определяется как забор ткани из живого или мертвого человеческого тела и ее имплантация в живое человеческое тело. Названный автор специально отмечает, что в процессе трансплантации обязательно присутствуют стадии забора органа или ткани у донора и их имплантация реципиенту. Указанные стадии присутствуют и в рамках тканевой инженерии (ТИ), однако тот материал, который берется от донора (ТИ-материал), отличается от продукта (ТИ-продукт), который будет имплантирован пациенту. По мнению автора, необходимо учитывать, используются при тканевом инжиниринге ткани и органы посмертных доноров, происходит ли их забор, например трахеи, которая в децеллюризованном виде выступает в качестве «каркаса» (матрикса) продукта тканевой инженерии. Если да, то такая тканевая инженерия принципиально не отличается от трансплантации. Если используются только стволовые клетки, полученные из костного мозга или другой ткани человека, и после их дифференциации они являются основой для создания продукта тканевой инженерии, то связь между забором клеток и имплантацией является слишком отдаленной ${ }^{35}$.

Таким образом, технология биопринтинга принципиальным образом отличается от трансплантологии. При «классической» трансплантологии берется плоть (ткань или орган) от живого или посмертного донора и эта же плоть пересаживается реципиенту. При тканевой инженерии и биопринтинге берутся клетки взрослого человека (пациента) и из них формируется аналог органа, который не является собственно «органом человека», а является клеточным инженерным конструктом, результатом биопечати.

Таким образом, биопринтинг не порождает такие фундаментальные этические вызовы, как классическая трансплантология. При биопринтинге человек не становится «ящиком с запчастями», бедный донор не эксплуатируется богатым реципиентом. При использовании аутологического биоматериала отсутствует донорство как таковое. Если же возникает необ- ходимость в заборе аллогенного биоматериала для биопринтинга, то это не влечет причинения вреда здоровью донора.

На этом основании можно утверждать, что Закон РФ от 22.12.1992 № 4180-1 «О трансплантации органов и (или) тканей человека» не подлежит применению в целях правового регулирования отношений, связанных с созданием и имплантацией биопринтных органов. Представляется допустимой «коммерциализация» отношений в сфере биопринтинга, возможность совершения возмездных сделок в данной сфере, а также ограниченный оборот «биопринтных» органов путем распространения на них режима объекта гражданского права.

В этой связи представляет интерес, что в англосаксонской доктрине уже высказываются позиции в пользу допустимости «коммерциализации» отношений, связанных с созданием и оборотом продуктов тканевой инженерии (клеточных инженерных продуктов), поскольку ТИ-технология предполагает использование не только человеческого биоматериала, но и синтетических материалов, например гидрогеля или полимерного матрикса. Активно используются и ксеногенные (животные) биоматериалы. Поэтому конечный продукт тканевой инженерии находится настолько далеко от своего исходного источника (человеческого биоматериала), что оборот таких продуктов не может рассматриваться в качестве коммерциализации тела человека или его отдельных частей ${ }^{36}$.

В англосаксонской судебной практике уже более века назад была сформулирована позиция об исключении из общего правила (common law exception), согласно которому является допустимым установление права собственности и оборот человеческих тканей теми лицами, которые видоизменили их посредством своих навыков и усилий (Doodeward v. Spence, 1908). Относительно недавно аналогичное правило было закреплено в статутном праве Великобритании (subsection 9 (с) Human Tissue Act, 2004).

Возникает также вопрос о возможности урегулирования отношений, связанных с созданием и имплантацией биопринтных органов, нормами Федерального закона от 23.06.2016 № 180-Ф3 «О биомедицинских клеточных продуктах». Так, согласно ст. 2 данного Закона био-

35 Von Tigerstrom B. Op. cit.

$36 \mathrm{CM} /$ : Gold R. E. Body Parts: Property Rights and the Ownership of Human Biological Materials. Georgetown University Press, 1996. Pp. 13-14; Von Tigerstrom B. Op. cit. 
медицинский клеточный продукт представляет собой комплекс, состоящий из клеточной линии (клеточных линий) и вспомогательных веществ либо из клеточной линии (клеточных линий) и вспомогательных веществ в сочетании с прошедшими государственную регистрацию лекарственными препаратами для медицинского применения, и (или) фармацевтическими субстанциями, включенными в государственный реестр лекарственных средств, и (или) медицинскими изделиями. Биомедицинские клеточные продукты могут быть как аутологичными, так и аллогенными. Данный Закон выделяет и комбинированные биомедицинские продукты, сочетающие аутологичный и аллогенный клеточный материал.

Однако, по мнению Д. В. Иванова и А. В. Чабаненко, к сожалению уделивших проблеме соотношения биопринтинга и биомедицинских клеточных продуктов всего один абзац в своей статье, остается открытым вопрос, будут ли нормы Федерального закона «О биомедицинских клеточных продуктах» применяться к отношениям, связанным с биопринтингом органов человека. По их мнению, было бы логичным урегулировать отношения по созданию биопринтных органов в названном Законе, а их трансплантацию - в Законе «О трансплантации органов и (или) тканей человека» 37 .

Действительно, Закон «О биомедицинских клеточных продуктах» в настоящий момент не способен урегулировать отношения, связанные с созданием и имплантацией биопринтных человеческих органов, поскольку он не охватывает отношения, связанные именно с имплантацией таких органов. В этом Законе прямо указано, что он не применяется к отношениям, связанным с донорством тканей и органов человека в целях их трансплантации. Биомеди- цинские клеточные продукты, по сути, являются особыми лекарственным средствами ${ }^{38}$, направленными на регенерацию некоторых тканей пациентов, например дермальные аналоги, которые были разработаны в целях восстановления пораженных кожных покровов пациентов.

Технология биопринтинга предполагает комбинацию «продуктов» (лекарственных препаратов, медицинских изделий, биологических препаратов и материалов) с проведением хирургических процедур по имплантации напечатанного органа ${ }^{39}$. При этом технология биопринтинга предполагает необходимость использования генной инженерии, связанной с перепрограммированием дифференцированных клеток в целях получения индуцированных плюрипотентных стромальных клеток. Поэтому технология биопринтинга вообще и биопринтный орган в частности не могут быть охвачены категорий биомедицинский клеточный продукт, предусмотренной действующей редакцией Закона «О биомедицинских клеточных продуктах».

Проведенный анализ позволяет констатировать, что в российском законодательстве отсутствуют нормы, позволяющие эффективно урегулировать отношения, связанные с созданием и имплантацией биопринтных органов человека. Действующее законодательство содержит в себе запреты, которые обусловлены этическими вызовами, не связанными с биопринтингом. Наличие таких запретов сдерживает развитие технологии биопринтинга. Это предопределяет необходимость в принятии специального законодательного акта, которым были бы урегулированы отношения, возникающие на всех стадиях использования технологии биопринтинга, в том числе и на стадии имплантации биопринтного органа.

\section{БИБЛИОГРАФИЯ}

1. Готье С. В., Попцов В. Н., Колоскова Н. Н., Захаревич В. М., Шевченко А. О., Муминов И. И., Никитина Е. А., Кван В. С., Халилулин Т. А., Закирьянов А. Р., Гольц А. М. Лист ожидания трансплантации сердца ФГБУ «НМИЦ ТИО имени академика В. И. Шумакова». Тенденции за период с 2010-го по 2017 год // Вестник трансплантологии и искусственных органов. - 2018. - Т. ХХ. - № 4. - С. 8-13.

2. Иванов Д. В., Чабаненко А. В. Закон о клеточных продуктах: прорыв или поражения? // Вестник новых медицинских технологий. - 2017. - Т. 24. - № 4. - С. 166-176.

37 Иванов Д. В., Чабаненко А. В. Закон о клеточных продуктах: прорыв или поражения? // Вестник новых медицинских технологий. 2017. Т. 24. № 4. С. 166-176.

38 См., например: Иванов Д. В., Чабаненко А. В. Указ. соч.

39 Varkey M. \& Atala A. Op. cit. 
3. Севастьянов В. И. Технология тканевой инженерии и регенеративной медицины // Вестник трансплантологии и искусственных органов. - 2014. - Т. XVI. - № 3. - С. 93-108.

4. Bauer H.-K. et al. Social and Legal Frame Conditions for 3D and Bioprinting in Medicine // International Journal of Computerized Dentistry. - 2016. - Vol. 19. - Iss. 4. - Pp. 293-299.

5. Brean D. H. Patent Enforcement in Cyberterritories (April 12, 2018) // Cardozo Law Abstract. - 2019. Vol. 40. (Forthcoming). - Available at SSRN: https://ssrn.com/abstract=3161823.

6. Desai D. R. \& Magliocca G. N. Patents Meet Napster: 3D Printing and the Digitization of Things // Georgetown Law Journal. - 2014. - Vol. 2. - Pp. 1691-1715.

7. Gold R. E. Body Parts: Property Rights and the Ownership of Human Biological Materials. - Georgetown University Press, 1996. - Pp. 13-14.

8. Goodwin M. Body Market: Race Politics \& Private Ordering // Arizona Law Abstract. - 2007. — Vol. 49. Pp. 599-636.

9. Goodwin M. Empires of the Flesh: Tissue and Organs Taboos // Alabama Law Abstract. - 2009. — Vol. 60. Iss. 5. - Pp. 1219-1248.

10. Kelly E. FDA Regulation of 3D-Printed Organs and Associated Ethical Challenges // University of Pennsylvania Law Abstract. - 2018. - Vol. 166. - Iss. 1. - Pp. 515-545.

11. Kennedy E. J., Giampetro-Meyer A. Gearing Up for the Next Industrial Revolution: 3D Printing, Home-based Factories and Modes of Social Control // Loyola University Chicago Law Journal. - 2015. - Vol. 46. Pp. 955-988.

12. Osborn L. Regulating Three-Dimensional Printing: The Converging Worlds of Bits and Atoms // San Diego Law Abstract. - 2014. - Vol. 51. - Pp. 553-620.

13. Steinbock B. The Morality of Killing Human Embryos // Journal of Law, Medicine \& Ethics. - 2006. - Vol. 34. Pp. 26-34.

14. Tran J. L. Bioprint or Not to Bioprint // North Carolina Journal of Law and Technology. - 2015. - Vol. 17. Iss. 1. - Pp. 123-178.

15. Varkey M. \& Atala A. Organ Bioprinting: A Closer Look at Ethics and Politics // Wake Forest Journal of Law \& Policy. - 2015. - Vol. 5. - Iss. 2. - Pp. 275-296.

16. Von Tigerstrom B. Human Tissue Legislation and New Medical Paradigm: Governing Tissue Engineering in Canada // McGill Journal of Law and Health. - 2015. - Vol. 8. - № 2. - Pp. 1-56.

17. Zaher W. An Update of Human Mesenchymal Stem Cell Biology and Their Clinical Use // Archives Toxicology. 2014. - Vol. 88. - Pp. 1069-1076.

18. Zuckermann A., Laufer G. Rationale Limits of Organ Donor Maximization for Heart Transplantation // Вестник трансплантологии и искусственных органов. - 2018. - Т. XX. - № 4. - С. 142-145.

Материал поступил в редакцию 22 марта 2019 г.

\section{BIOPRINTING TECHNOLOGY AS A LEGAL CHALLENGE: DETERMINING THE MODEL OF LEGAL REGULATION ${ }^{40}$}

BOGDANOV Dmitry Evgenevich, Doctor of Law, Professor of the Department of Civil Law of the Kutafin Moscow State Law University (MSAL)

debogdanov@msal.ru

125993, Russia, Moscow, ul. Sadovaya-Kudrinskaya, d. 9

Abstract. The technology of 3D printing creates serious challenges to the legal system that in its development is lagging behind scientific and technological progress. The development of 3D printing technology leads to the "digitalization" of objects of the material world when the boundaries between the physical world and the digital space are blurred. If 3D printing digitalizes objects of the material world, bioprinting digitalizes the human body. An individual tends to depend on the digital incarnation of his body or its individual organs in the corresponding electronic 3D models.

40 The study was carried out with the financial support of RFBR within the framework of the scientific project No. 18-29-14027 mk «The Concept of Legal Regulation of Relations concerning Genomic Research in the Field of creation and Use of Bioprintic Human Organs». 
Bioprinting is aimed at the formation of a new medical paradigm that will result in overcoming the deficiency of human organs and tissues in the field of transplantology. The discovery of the possibility of reprogramming differentiated cells and obtaining induced pluripotent stem cells eliminates the ethical and legal problem associated with the use of stem cells of the embryo. This should be taken into account in the development of a model of legal regulation of relations connected with the creation of bio-print human organs.

Bioprint organs are synthetic organs, so the relations associated with their creation and implantation need independent legal regulation. Contemporary transplantology legislation and bans and prohibitions contained in it do not take into account the features of the creation of organs through $3 D$ bioprinting. It is acceptable to commercialize relations in the field of bioprinting, to perform non-gratuitous transactions in this area, as well as to permit limited turnover of «bioprinting» organs subjecting them to the regulation applied to any other objects of civil law.

Legislation on biomedical cellular products is also not able to regulate relations related to the creation and implantation of bio-printed human organs. Thus, the need arises to adopt a special legislative act aimed at regulating relations at all stages of the use of bioprinting technology.

Keywords: 3D printing technology, bioprinting, bioprinting organ, tissue engineering, biomedical cell product, induciable pluripotent stem cell, embryo, transplantation, donation, turnover organs and tissues of the person, legal regulation.

\section{REFERENCES}

1. Gote S. V., Poptsov V. N., Koloskova N. N., Zakharevich V. M., Shevchenko A. O., Muminov I. I., Nikitina E. A., Kvan V. S., Khalilulin T. A., Zakiryanov A. R., Golts A. M. List ozhidaniya transplantatsii serdtsa fgbu «NMITs TIO imeni akademika V. I. Shumakova». Tendentsii za period s 2010-go po 2017 god [A Waiting List of heart transplantation of the FSBI «Academician V.I.Shumakov Federal Research Center of Transplantology and Artificial Organs» Tendencies for the period from 2010 to 2017]. Vestnik transplantologii i iskusstvennykh organov [Annuls of Transplantology and Artificial Organs]. 2018. Vol. XX. No. 4. P. 8-13. (In Russ.)

2. Ivanov D. V., Chabanenko A. V. Zakon o kletochnykh produktakh: proryv ili porazheniya? [The Law on Cellular Products: A Breakthrough or Defeat?]. Vestnik novykh meditsinskikh tekhnologiy [Journal of New Medical Technologies]. 2017. Vol. 24. No. 4. P. 166-176. (In Russ.)

3. Sevastyanov V. I. Tekhnologiya tkanevoy inzhenerii i regenerativnoy meditsiny [Technology of tissue engineering and regenerative medicine]. Vestnik transplantologii i iskusstvennykh organov [Annuls of Transplantology and Artificial Organs]. 2014. Vol. XVI. No. 3. P. 93-108. (In Russ.)

4. Bauer H.-K. et al. Social and Legal Frame Conditions for 3D and Bioprinting in Medicine. International Journal of Computerized Dentistry. 2016. Vol. 19. Iss. 4. P. 293-299.

5. Brean D. N. Patent Enforcement in Cyberterritories (April 12, 2018). Cardozo Law Abstract. 2019. Vol. 40. (Forthcoming). Available at SSRN: https://ssrn.com/abstract=3161823.

6. Desai Deven R. \& Magliocca Gerard N. Patents Meet Napster: 3D Printing and the Digitization of Things. Georgetown Law Journal. 2014. Vol. 2. P. 1691-1715.

7. Gold R. E. Body Parts: Property Rights and the Ownership of Human Biological Materials. Georgetown University Press, 1996. P. 13-14.

8. Goodwin M. Body Market: Race Politics \& Private Ordering. Arizona Law Abstract. 2007. Vol. 49. P. $599-636$.

8. Goodwin M. Empires of the Flesh: Tissue and Organs Taboos. Alabama Law Abstract. 2009. Vol. 60. Iss. 5. P. 1219-1248.

10. Kelly E. FDA Regulation of 3D-Printed Organs and Associated Ethical Challenges. University of Pennsylvania Law Abstract. 2018. Vol. 166. Iss. 1. P. 515-545.

11. Kennedy E. J., Giampetro-Meyer A. Gearing Up for the Next Industrial Revolution: 3D Printing, Home-based Factories and Modes of Social Control. Loyola University Chicago Law Journal. 2015. Vol. 46. P. 955-988.

12. Osborn L. Regulating Three-Dimensional Printing: The Converging Worlds of Bits and Atoms. San Diego Law Abstract. 2014. Vol. 51. P. 553-620.

13. Steinbock B. The Morality of Killing Human Embryos. Journal of Law, Medicine \& Ethics. 2006. Vol. 34. P. 26-34. 
14. Tran Jasper L. Bioprint or Not to Bioprint. North Carolina Journal of Law and Technology. 2015. Vol. 17. Iss. 1. P. 123-178.

15. Varkey M. \& Atala A. Organ Bioprinting: A Closer Look at Ethics and Politics. Wake Forest Journal of Law \& Policy. 2015. Vol. 5. Iss. 2. P. 275-296.

16. Von Tigerstrom B. Human Tissue Legislation and New Medical Paradigm: Governing Tissue Engineering in Canada. McGill Journal of Law and Health. 2015. Vol. 8. No. 2. P. 1-56.

17. Zaher W. An Update of Human Mesenchymal Stem Cell Biology and Their Clinical Use. Archives Toxicology. 2014. Vol. 88. P. 1069-1076.

18. Zuckermann A., Laufer G. Rationale Limits of Organ Donor Maximization for Heart Transplantation. Vestnik transplantologii $i$ iskusstvennykh organov Bulletin of Transplantologii i Iskusstvennykh Organov [Annuls of Transplantology and Artificial Organs]. 2018. Vol. XX. No. 4. P. $142-145$. 